\title{
Periferik kan mononükleer hücrelerin primer paratiroit dokusu hücreleri ile ko-kültürünün verimliliği
}

\section{Efficiency of co-cultured peripheral blood mononuclear cells with primary parathyroid tissue cells}

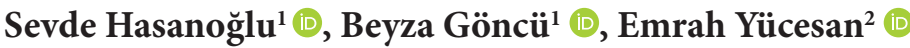

Bezmialem Vakıf Üniversitesi, ${ }^{1}$ Deneysel Uygulama ve Araștırma Merkezi, ${ }^{2}$ Tıp Fakültesi, Tibbi Biyoloji Anabilim Dalı, İstanbul, Türkiye

ORCID: S.H. 0000-0003-2378-1535; B.G. 0000-0001-6026-8218; E.Y. 0000-0003-4512-8764

Sorumlu yazar/Corresponding author: Emrah Yücesan, Bezmialem Vakıf Üniversitesi, 'Deneysel Uygulama ve Araştırma Merkezi, İstanbul, Türkiye

E-posta: emrahyucesan@yahoo.com

Basvuru/Submitted: 31.12 .2019

Kabul/Accepted: 10.02 .2020

Atıf/Citation: Hasanoglu S, Goncu B, Yucesan E. Efficiency of co-cultured peripheral blood mononuclear cells with primary parathyroid tissue cells. Sağlık Bilimlerinde İleri Araştırmalar Dergisi 2020; 3(1): 5-12.

https://doi.org/10.26650/JARHS2020-668235
ÖZ

Organ yetmezliğinde, nakil öncesi uygulanan immün testler ekonomik anlamda maliyetli ve uzman ekip gözetiminde uygulanan hassas testlerdir. Uygulaması görece daha kolay olan in vitro ko-kültür modelleri ile daha ekonomik ve uygulama kolaylığı olan bir yöntem geliştirilmesi hedeflenmiștir. Kalııı hipoparatiroidi hastalarına ait periferik kan mononükleer hücreleri $(n=4)$ ile iki farklı donöre ait paratiroit hücresinin ayırıcı bir bariyer olmadan ve bariyer kullanılarak ko-kültüre edilmesiyle bir model oluşturulmuştur. Parathormon ve hücre sayım takibi 24 ve 72. saatlerde gerçekleştirilmiştir. İki ayrı paratiroit hücre grubunda parathormon seviyesi anlamlı şekilde artarken, hücre sayısı anlamlı şekilde her iki grupta da azalmıştır. Kontrol grubu ile karşılaştırıldığında ise ayırıcı bariyer kullanıldığı ve kullanılmadığı her iki durumda da periferik kan mononükleer hücreleri yabancı paratiroit hücrelerine karşı anlamlı bir değișim göstermemiștir. Bu çalıșmada uygulanan ko-kültür modeli, manipülasyonu diğer hassas testlere göre daha kolaydır. Temelde, nakil sağ kalımının öngörülmesi sürecinin daha az maliyetle belirlenebilmesi için gerçekleştirilmiştir. Fakat uygulanan iki ayrı ko-kültür modeli hem ayırıcı bir bariyer eşliğinde hem de ayırıcı bir bariyer olmadan paratiroit hücreleri ve PKMH için anlamlı bir farklılık oluşturmamıştır. İlerleyen çalışmalarda daha hassas testlerin uygulanarak sağ kalım öngörülmesi için farklı yöntemlerin denenmesi hedeflenmektedir.

Anahtar Kelimeler: PKMH, primer doku hücreleri, paratiroit, ko-kültür

\section{ABSTRACT}

In organ failure, pre-transplant immunoassays are cost-effective and sensitive tests performed under the supervision of a specialist team. The aim of this study is to develop a more economical and easy to handle method that is relatively easy to perform in vitro with coculture models. Peripheral blood mononuclear cells from permenant hypoparathyroidism patients $(n=4)$ were co-cultured with parathyroid cells of two different donors both with and without a barrier. Parathormone and cell counting were determined at 24 and 72 hours of cultivation. Parathormone levels were significantly increased in two separate parathyroid cell groups, whereas the cell number was significantly decreased in both groups. Peripheral blood mononuclear cells did not show a significant change against foreign parathyroid cells in both co-culture groups with barriers and without barriers when compared with the control group. In this study, the co-culture model, which is easier to manipulate than other sensitive tests, was performed. Basically, in order to determine the process of predicting the survival of the transplant which was carried out at a lower cost. However, the two separate co-culture models did not create a significant difference for parathyroid cells and peripheral blood mononuclear cells both in the presence of a barrier and without a barrier. In future studies, different methods should be used to experience prediction of survival by performing more sensitive tests.

Keywords: PBMC, primary tissue cells, parathyroid, co-culture 


\section{GİRIŞ}

Organ nakli, 20. yüzyılın ikinci yarısında tıp alanında görülen en önemli gelişmelere sahne olan disiplinler arası bir araştırma alanıdır. Nakil, çoğu durumda son dönem organ yetmezliği için tek ve en etkili tedavi olmaya devam etmektedir. Yüksek kaliteli ve etkili organların temini, nakil için her zaman en önemli adım olmuştur (1). Organları veya dokuları bir insandan diğerine nakletme girişimleri 1967 yılında insan majör histo-kompetabilite kompleksinin (MHC) keşfedilmesine kadar uzun yıllar boyunca başarısız olmuştur. MHC antijenleri için verici ve alıcı eşleşmesinin greft kabulü üzerinde anlamlı pozitif etkisi olduğu gösterilmiştir. Greftlerin toleransı veya rejeksiyonunda immün sistemin; antikorlar, antijen sunan hücreler, yardımcı ve sitotoksik T hücreleri, immün hücre yüzey molekülleri ve sitokinler gibi farklı bileşenlerinin rolleri açıklığa kavuşturulmuştur (2). Rejeksiyon, allotransplantasyonun temel problemlerinden biridir. Nakledilen doku ve organların uzun süre hayatta kalması ve işlevi, transplantın insan lökosit antijeni (HLA) eksprese eden antijen sunan hücrelerden yoksun olmasına bağlıdır (3). Günümüzde gelişen teknoloji sayesinde alıcı ile verici arasında HLA doku tiplendirme testleri, panel reaktif antikor (PRA) taraması, sanal çaprazlama (lenfosit crossmatch CXM) testleri, komplemana bağlı sitotoksisite (mikrolenfositotoksisite crossmatch-CDC-CXM), tek HLA molekülleri ile kaplanmış solid faz testi (single antigen bead-SAB), donör spesifik antikor (DSA) tarama testi gibi birçok immünolojik test kullanılabilmektedir (4). Bu testlerin uygulanması için periferik kandan elde edilen DNA, serum örnekleri ve izole edilen periferik kan mononükleer hücreler (PKMH) kullanılmaktadır. Özellikle PKMH lenfosit, monosit veya makrofaj gibi çekirdeğe sahip bir kan hücresi olması nedeniyle, bu tarz çalışmalardaki en uygun hücre tipidir. $\mathrm{Bu}$ kan hücreleri immün sistemde enfeksiyonla savaşmak için kritik bir bileşendir. PKMH'ler bağ $1 s ̧ 1 k l 1 k$ sistemine seçici yanıtlar verir ve insan vücudundaki ana immün sistem hücreleridir (5).

Kalıcı Hipoparatiroidizm (KH), düşük kalsiyum ve düşük parathormon (PTH) seviyeleri ile karakte- rize bir hastalıktır. KH'nin en yaygın sebebi tiroit cerrahisi sırasında paratiroit bezlerinin alınması ya da kanlanmasının hasar görmesidir (6). KH'de en sık görülen komplikasyonlar ise: zayıflık, kas fonksiyon kaybı, miyozit, fasiit, katarakt diş malformasyonları ve nefropatidir. $\mathrm{KH}$ tedavisinde $\mathrm{D}$ vitamini ve oral kalsiyum takviyesi standart semptomatik tedavi yöntemleridir. Fakat bu takviyelerin uzun süre kullanılmasının, hastanın üzerinde birçok yan etkisi vardır (7). Paratiroit allotransplantasyonu (PA) ise alternatif ve hastalığ tedavi edici tek yöntem olarak görülmektedir (8). PA; hücre tipi PA ve doku tipi PA olmak üzere iki sınıfa yapılmaktadır. Fakat her iki yönteminde olumlu ve olumsuz yönleri vardır. Doku tipi PA daha az ekipman gerektirir ve uygulanması kolaydır ancak uzun süreli immünsüpresif tedavi gerektirir. Hücre tipi PA ise yararlı olmasıyla birlikte hücrelerin dondurulma ve çözdürülme işlemi nedeniyle hücre canlılığının sürdürülmesi zordur (7). Transplantasyonda redde neden olan dokunun taş1dığı immünolojik belirteçlerin kültür ortamında manipülasyonu ve HLA ekspresyonu az hücrelerin seçimi kullanılan farklı tekniklerdir. $\mathrm{KH}$ nadiren hayati tehlikeye sebep olan bir durum olduğundan, tedavi aşamasında immünsüpresif uygulanması tercih edilmez (8). Tüm bu alternatif süreçlere rağmen, günümüzde hipoparatiroidizm tedavisine yönelik standart bir yaklaşım bulunmamaktadır (6).

PA'da, immün testlerle paralel olacak şekilde daha ekonomik, pratik ve kolay uygulanabilir bir yöntem ülkemizin ekonomik gerçekliğinde gereklilik arz etmektedir. Bu gereklilikten yola çıkarak çalışmamızda dört KH hastasına ait PKMH'leri ile iki farklı donöre ait paratiroit hücresinin ko-kültüre edilmesiyle bir model oluşturulmuştur. Önerdiğimiz model ile, henüz nakil işlemini gerçekleştirmediğimiz hastalardan elde edilecek PKMH'ler kullanarak, naklin olası sağkalımını ön görmeyi hedeflemekteyiz. Bu sayede ilerleyen dönemde nakil başarasının doğrudan arttırılmasını hedeflemekteyiz.

\section{GEREÇ VE YÖNTEM}

Bu çalışma, Yerel Girişimsel Olmayan Etik Kurul'dan (Onay numarası: 71306642-050.01.04) onay 
alındıktan sonra, gerekli onam formlarının temini sonrasında yapılmıştır ve protokollerin tümü Helsinki Deklarasyonunun etik kurallarına uygun olarak gerçekleştirilmiştir.

Örneklem: Çalışmada donör grubu olarak nakil sürecinde hali hazırda tarafımızda bulunan sekonder hiperparatiroidi tanılı iki hastaya ait paratiroit dokusu kullanılmıştır. Alıcı grubu için ise kalıcı hipoparatiroidi tanılı (en az >3 yıldır kalıcı hipoparatiroidi tanılı) dört adet hastaya ait kan örnekleri kullanılmıştır. Periferik kan örnekleri heparinli tüplere 10 $\mathrm{ml}$ olmak üzere toplanmıştır.

PKMH izolasyonu: $10 \mathrm{ml}$ heparinli tüpe alınmış kanlar 1:1 oranında fosfat tamponlu salin ile dilüe edilmiştir. Ardından 1:3 (fikol+ tam kan) oranında fikol üzerine yavaşça eklenerek oda sıcaklığında 2500 rpm'de 25 dakika santrifüjlenmiştir. Santrifüjden sonra hücreler gradient farkına göre ayrılmış, fikol ile plazma arasindaki ara fazda yer alan ince bir tabaka halindeki PKMH'ler mikropipetle temiz bir tüpe aktarılmıştır. İki kez PBS ile oda sıcaklığında 1800 rpm'de beş dakika santrifüjlenerek yıkanmıştır. Son yıkamanın ardından üst faz dökülerek altta kalan pellet kısmı RPMI kültür medyumu ile homojen hale getirilmiştir.

Paratiroit Hücre İzolasyonu: 0,3 gram ağırlığındaki paratiroit dokularından hücre izolasyonu Göncü ve arkadaşlarının (9) tarif ettiği şekilde enzimatik olarak gerçekleştirilmiştir.

Ko-Kültür: Paratiroit dokusundan izole edilen donör grubuna ait hücrelerden kuyu başı $1,5 \times 10^{6}$

hücre olmak üzere RPMI (\%10 FBS, \%1 P/S, \%1 NEAA) medyum kullanılarak 48 kuyulu plaka içine ekilmiştir. Plakanın kuyu içerisindeki ayırıcı bölmesine ise alıc1 grubuna ait izole edilen PKMH'ler ekilmiştir. Ayırıcı bariyerde, hücreler aynı medyum ortamını paylaşmakta fakat fiziksel olarak ayrı bölmelerde bulunmaktadırlar. Aynı düzenek diğer deney grubu için ayırıcı bölme/bariyer olmadan gerçekleştirilmiştir. Kültür her iki deney grubu için de $37^{\circ} \mathrm{C}$ 'de $\% 5 \mathrm{CO}_{2}$ içeren inkübatörde 30 rpm'de orbital çalkalayıcı üzerinde dört gün boyunca devam ettirilmiștir.

Ko-kültür ve bir arada kültüre edilen tüm gruplar için kontrol gurubu olarak; paratiroit hücreleri ayrı bir kuyuda aynı zaman aralıkları için tek başına kültüre edilmiştir.

Hücre sayımı ve Parathormon ölçümü: Kültür süresince 24. ve 72. saatlerde paratiroit hücresi ve PKMH sayımı 20 kat dilüsyon ile Muse hücre analiz cihazında (Merck Millipore, Germany) yapılmıştır. Aynı zamanda 24. ve 72. saatlerde PTH ölçümleri PTH EIA kit (RayBiotechInc., GA, USA) protokolüne uygun olarak gerçekleştirilmiştir. $450 \mathrm{~nm}$ dalga boyunda absorbans ölçümü Mark Microplate Absorbance Reader (Bio-Rad,USA) kullanılarak yapılmıştır.

\section{SONUÇLAR}

Donör grubundan; Donör 1 (D1)'e ait olan dokudan $\% 60,5$ canlılık oranıyla $24 \times 10^{6}$ hücre, Donör 2 (D2)'ye ait olan dokudan ise $\% 87,5$ canlılık oranıla $23 \times 10^{6}$
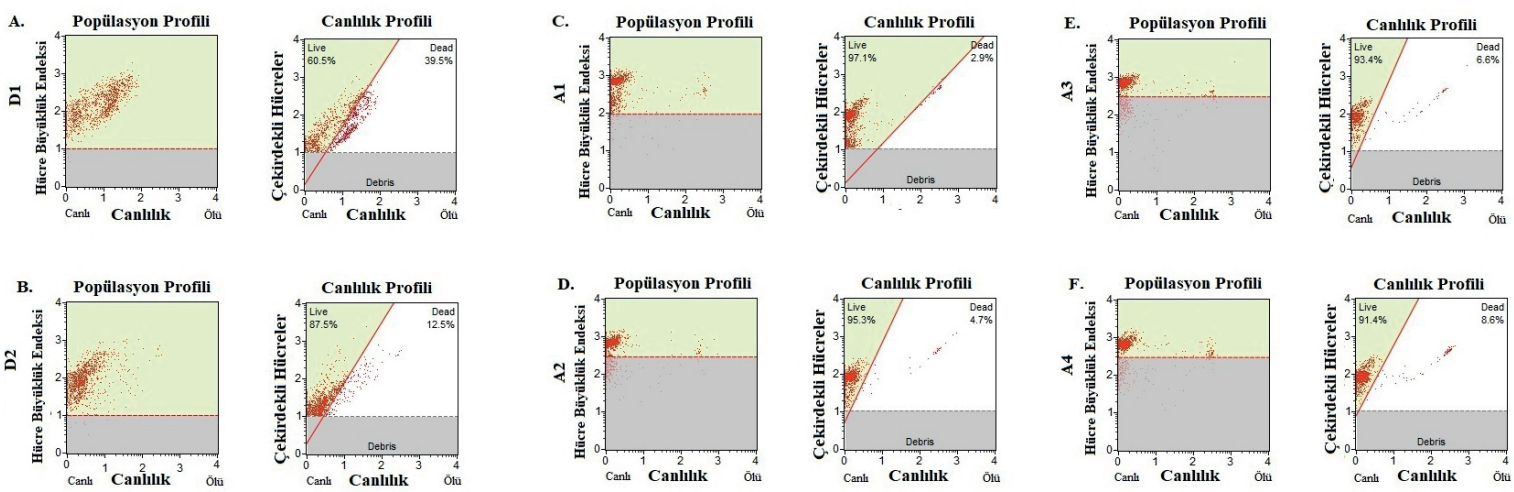

Şekil 1. Dönor ve alıcı grubundan izole edilen hücrelerin popülasyon profilleri ve canlılık yüzdeleri. A. Dl'e ait paratiroit hücreleri, B. D2'ye ait paratiroit hücreleri, C. Al'e ait PKMH'ler, D. A2'ye ait PKMH'ler, E. A3'e ait PKMH'ler, F. A4'e ait PKMH'ler. (D1: Donör 1, D2: Donör 2, A1:Alıc1 1, A2: Alıc1 2, A3: Alıc1 3, A4: Alıc1 4, PKMH: Periferik kan mononükleer hücreler). 
hücre izole edilmiştir. İzole edilen PKMH'lerine ait Alıcı 1 (A1) için \%93,4 canlılıkta 14x106 hücre, Alıcı 2 (A2) için \%96 canlllıkta $12 \times 10^{6}$ hücre, Alıcı 3 (A3) için $\% 89,9$ canlilıkta $7 \times 10^{6}$ ve Alıc1 4 (A4) için \%91,2 can-

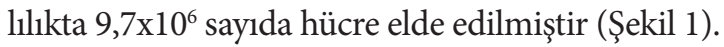

Paratiroit dokusundan izole edilen donör grubuna ait hücrelerden $3 \times 10^{6}$ hücre/kuyu başı olmak üzere 48 kuyulu plaka içine ekilmiştir. Ayırıcı bölme olmadan, aynı kuyu içerisine alıcı grubuna ait izole edilen $1,5 \times 10^{6}$ sayıda PKMH ekilmiştir. Ko-kültür gruplarına ait şematik gösterimi Şekil 2'de verilmiştir. Paratirot hücreleri ve bu hücreler ile ko-kültüre edilen PKMH'ne ait PTH ölçümleri Tablo 1'de gösterilmiştir. Kontrol grubu olarak kullanılan paratiroit hücre kültür grubu; Dl'e ait paratiroit hücre sayısı 24. saat için $0,81 \times 10^{6}(\% 59,7$ canlllık) ve 72 . saat için 0,49x10 (\%72,1 canlılık) belirlenmiştir. Aynı şekilde, D2'ye ait paratiroit hücre sayısı 24 . saat için $2,82 \times 10^{6}$ (\%99,3 canlllık) ve 72 . saat için $0,89 \times 10^{6}(\% 97,4$ canlılık) olarak belirlenmiştir.

Ayırıcı bölme olmadan; paratiroit hücreleri ile beraber kültüre alınan PKMH hücrelerinin ko-kültürü
24 ve 72. saat takip edilerek, bu sonuçlara ait canlılık profili değişimi Şekil 3'de ayrıntılı olarak gösterilmiştir. Aynı gruplardan, aynı zaman aralıkları süresince PTH ölçümü tamamlanmış ve Tablo-1'de verilmiştir. Ko-kültür aşamasının ilk kısmı olan herhangi bir ayırıcı bariyer olmadan, bir arada kültüre edilen PKMH ve paratiroit hücrelerinin; PTH seviyelerinin kültür süresinde anlamlı şekilde arttığı gözlenmiştir (D1 ile ko-kültüre edilen dört alıcı için $\mathrm{p}=0,0036$ ve D2 ile ko-kültüre edilen dört alıcı için p=0,0141), aynı şekilde; hücre sayılarının da anlamlı şekilde azaldığı belirlenmiştir ( $\mathrm{p}=0,0004$ ve $\mathrm{p}=0,0382$ sirasiyla).

Ayırıcı bölme kullanılarak gerçekleştirilen ko-kültür aşamasında 24 ve 72 . saat popülasyon profilleri ve canlılık yüzdeleri değişimi Şekil 4'te ayrıntılı olarak gösterilmiştir. PTH salınımının her grup için kültür sürecinde anlamlı şekilde arttığı belirlenmiştir (D1 ile ko-kültüre edilen dört alıcı için $\mathrm{p}=0,0124$ ve D2 ile ko-kültüre edilen dört alıcı için $\mathrm{p}=0,0011$ ). Filtre üzerinde kalan $\mathrm{PKMH}$ 'ler filtre üzerinden al1namadığı için ayrı olarak sayılamamıştır. Bununla birlikte, hücre sayım sonuçları değerlendirildiğinde,

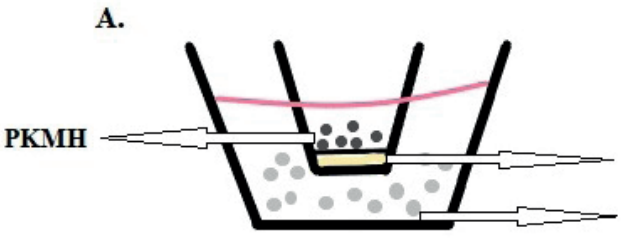

Ayırıcı Bariyerli
Ayırıcı Bariyer

Paratiroit Hücreleri

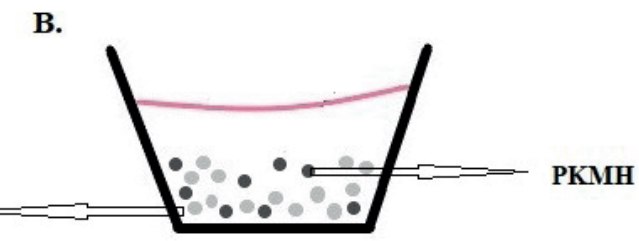

Ayırıcı Bariyersiz

Şekil 2. Uygulanan ko-kültür modelinin şematik gösterimi. A. Ayırıcı bariyer ile birlikte ko-kültür modeli. B. Ayırıcı bariyer olmadan ko-kültür modeli.

Tablo 1. Dokudan izole edilen paratiroit hücreleri tek başına ve bu hücreler ile beraber ko-kültüre edilen (ayırıcı bariyerli ve ayırıcı bir bariyer olmadan) PKMH’lere ait PTH ölçümleri (ng/ml)

\begin{tabular}{|c|c|c|c|c|c|c|c|}
\hline \multirow{2}{*}{ Sadece D1 } & 24. saat & \multirow{2}{*}{\multicolumn{2}{|c|}{$\begin{array}{l}2,26 \\
4,01\end{array}$}} & \multirow{2}{*}{\multicolumn{2}{|c|}{$\begin{array}{l}16,2 \\
20,6 \\
\end{array}$}} & 24. saat & \multirow{3}{*}{ Sadece D2 } \\
\hline & \multirow[t]{2}{*}{ 72. saat } & & & & & 72. saat & \\
\hline & & $\begin{array}{c}\text { Ayırıcı } \\
\text { Bariyerli }\end{array}$ & $\begin{array}{c}\text { Ayırıcı } \\
\text { Bariyersiz }\end{array}$ & $\begin{array}{c}\text { Ayıricı } \\
\text { Bariyerli }\end{array}$ & $\begin{array}{c}\text { Ayırıcı } \\
\text { Bariyersiz }\end{array}$ & & \\
\hline \multirow{2}{*}{ A1/D1 } & 24. saat & 2,63 & 2,75 & 17,9 & 18,2 & 24. saat & \multirow{2}{*}{ A1/D2 } \\
\hline & 72. saat & 4,25 & 5,11 & 22,0 & 26,1 & 72. saat & \\
\hline \multirow{2}{*}{ A2/D1 } & 24. saat & 2,69 & 2,68 & 15,8 & 18,2 & 24. saat & \multirow{2}{*}{ A2/D2 } \\
\hline & 72. saat & 3,67 & 4,10 & 18,3 & 23,8 & 72. saat & \\
\hline \multirow{2}{*}{ A3/D1 } & 24. saat & 2,58 & 2,73 & 15,6 & 14,4 & 24. saat & \multirow{2}{*}{ A3/D2 } \\
\hline & 72. saat & 3,68 & 3,85 & 21,9 & 17,3 & 72. saat & \\
\hline \multirow{2}{*}{ A4/D1 } & 24. saat & 2,61 & 3,66 & 14,9 & 14,4 & 24. saat & \multirow{2}{*}{ A4/D2 } \\
\hline & 72. saat & 2,68 & 3,78 & 22,7 & 22,3 & 72. saat & \\
\hline
\end{tabular}




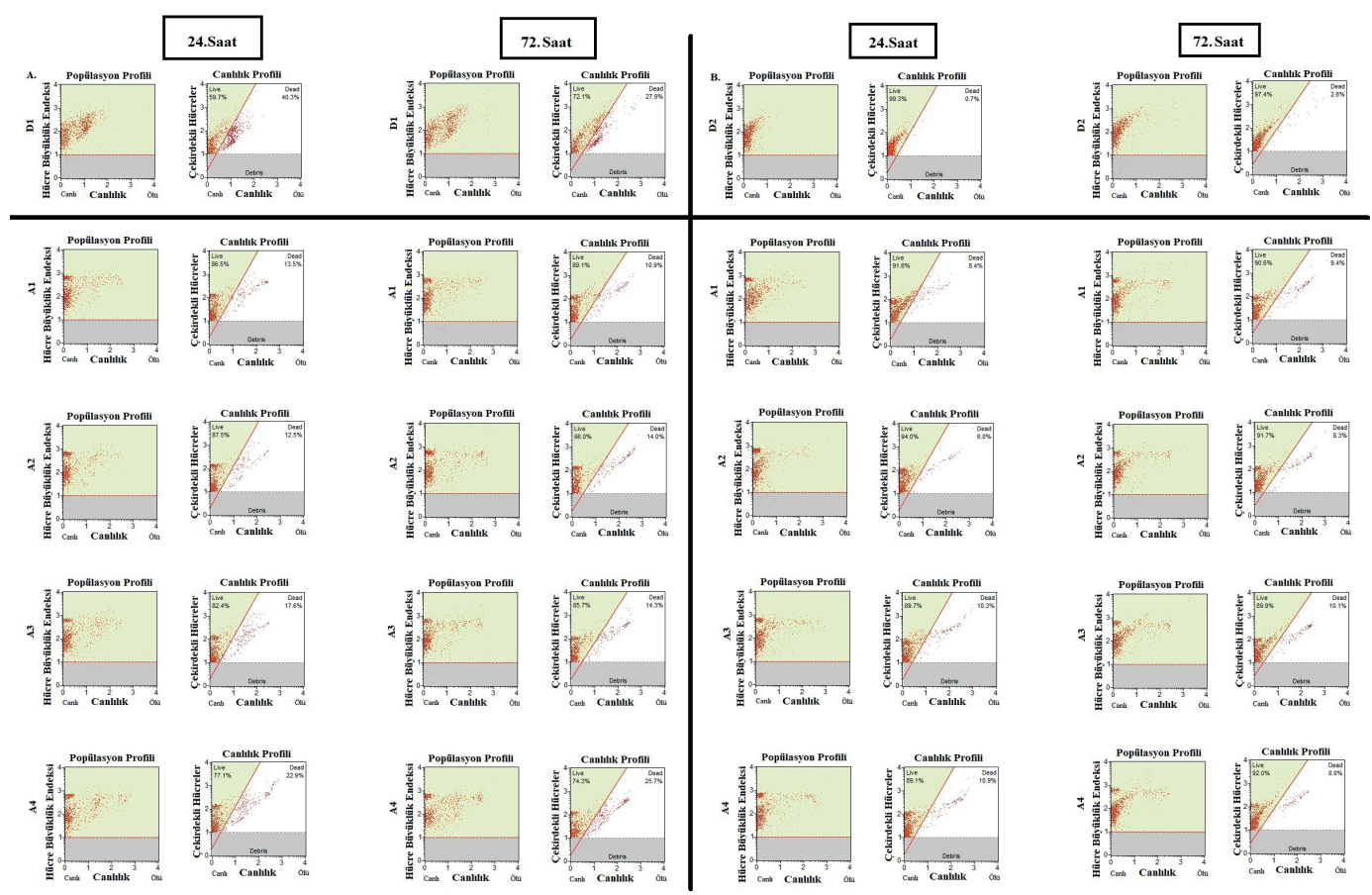

Şekil 3. Donör grubuna ait paratiroit hücreleri ile alıcı grubuna PKMH’lerin ayırıcı bariyer olmadan ko-kültürü sırasında 24 ve 72. saatteki popülasyon profilleri ve canlılık yüzdeleri. A. D1'e ait kontrol grubu hücreleri ve D1 ile dört farklı alıcıya ait PKMH'lerin ko-kültürü, B. D2'ye ait kontrol grubu hücreleri ve D2 ile dört farklı alıcıya ait PKMH'lerin ko-kültürü. (D1: Donör 1, D2: Donör 2, A1:Alıc1 1, A2: Alıc1 2, A3: Alıc1 3, A4: Alıc1 4, PKMH: Periferik kan mononükleer hücreler).

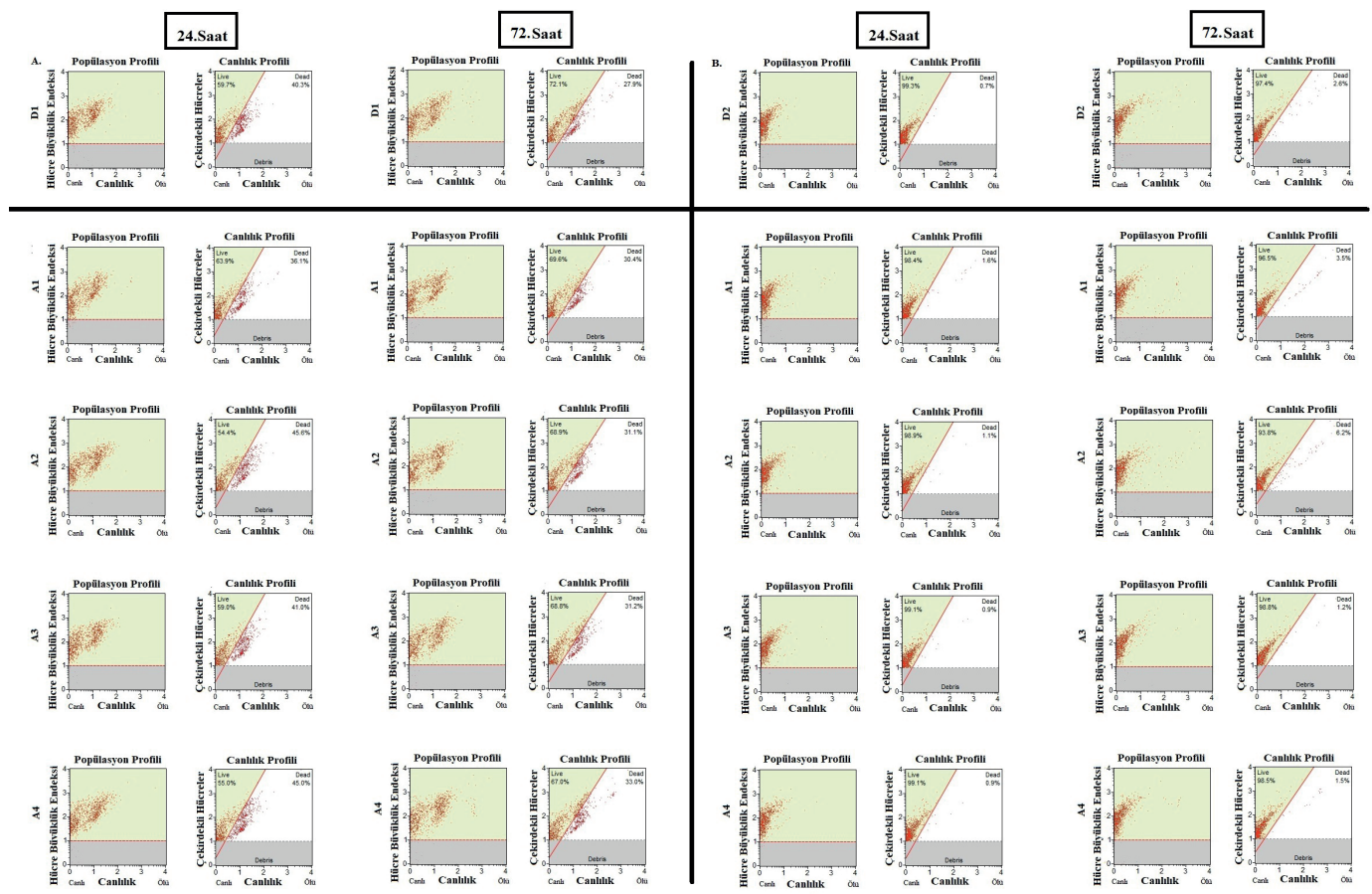

Şekil 4. Donör grubuna ait paratiroit hücreleri ile alıcı grubuna ait PKMH’lerin ayırıcı bariyer ile birlikte ko-kültürü sırasında 24 ve 72. saat popülasyon profilleri ve canlılık yüzdeleri. A. D1'e ait kontrol grubu hücreleri ve D1 ile dört farklı alıcıya ait PKMH'lerin ko-kültürü, B. D2'ye ait kontrol grubu hücreleri ve D2 ile dört farklı alıcıya ait PKMH'lerin ko-kültürü. (D1: Donör 1, D2: Donör 2, A1:Alıc1 1, A2: Alıc1 2, A3: Alıc1 3, A4: Alıc1 4, PKMH: Periferik kan mononükleer hücreler). 

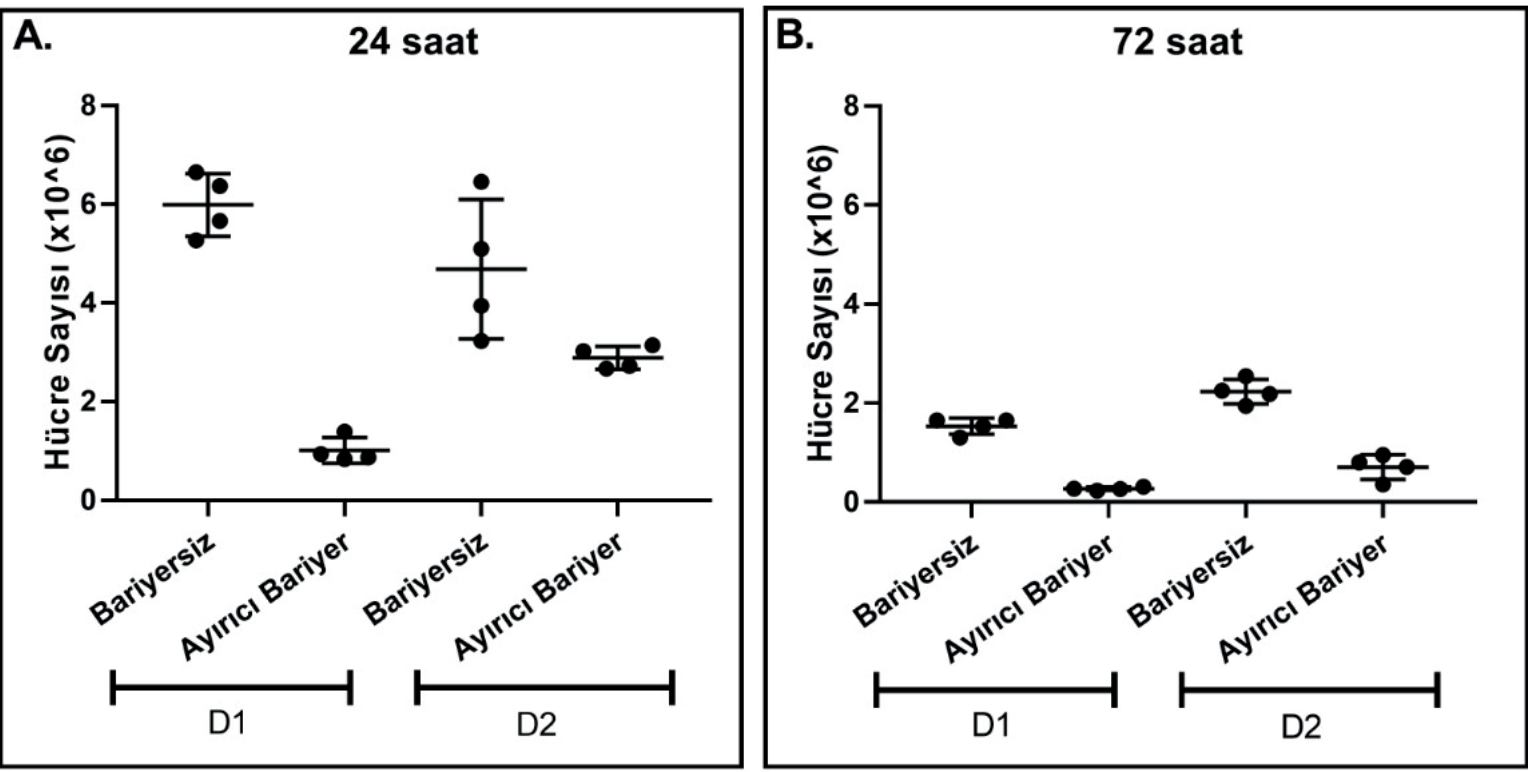

Șekil 5. Donör grubuna ait paratiroit hücreleri ile alıcı grubuna ait PKMH'lerin ayırıcı bariyer ile birlikte ve ayırıcı bariyer olmadan ko-kültürü sırasındaki hücre sayıları. A. 24.saate ait hücre sayıları, B. 72.saate ait hücre sayıları. (D1: Donör 1, D2: Donör 2, PKMH: Periferik kan mononükleer hücreler).

aynı kültür medyum ortamını paylaşan paratiroit hücrelerinin kültür sürecinde anlamlı şekilde azald1$\breve{g}$ ı belirlenmiştir (D1 ile ko-kültüre edilen dört alıc1 için $\mathrm{p}=0,0096$ ve D2 ile ko-kültüre edilen dört alıcı için $\mathrm{p}<0,0001$ ) (Şekil 5).

\section{TARTIŞMA}

Paratiroit naklinde bugüne kadar birçok klinik seri raporlanmıştır bunların çok bir kısmında immünolojik parametreler değerlendirilerek raporlanmıştır. Bugüne kadar literatürde bildirilen en uzun süreli nakil verisi Alfrey ve ark. 1992'de yaptıkları nakle aittir. Bu nakilde böbrek nakliyle eş zamanlı olarak paratiroit naklide yapılmış ve ağır immünsüpresif ilaçlarla hasta 13 yıl boyunca takip edilmiştir. Bu nakilde gerçekleştirilen immünolojik testler üç alel uyumu (HLA-A, -B ve-DR) ve lenfosit-CXM negatif olarak gerçekleştirilmiştir (10). Paratiroit nakli ile ilgili en geniş immünolojik tarama testi kriterleri 2019 yılında Yücesan ve ark. tarafından gerçekleştirilmiş olup; negatif PRA, negatif lenfosit-CXM ve negatif mikrolenfositotoksisite testi ile gerçekleştirilen nakildir (11). Paratiroit nakli ile ilgili literatürdeki immünolojik kriterler halen standardize edilmemiştir. Fakat her nakil birimi kendi kriterler ve takip parametrelerini belirleme konu- sunda karar alma yetkisine sahiptir (7). Bununla birlikte, lenfosit CXM ve mikrolenfositotoksisite gibi testler için hem alıcı hem de donörün aynı anda kan vermesi gerekmektedir. Ayrıca bu testlerin yapılabilmesi için uzman personel ve gerekli teknik koşullarının sağlanması için uzman bir merkez gereksinimi vardır (4). Aynı anda kan verme işlemi, organizasyon süreçlerinin gerçekleştirilmesi ve takibi açısından zorluk oluşturmaktadır. Bu testlerin zorlukları sebebiyle farklı test yöntemlerine ihtiyaç duyulmaktadir.

Son 20 yllda in vitro kültür sistemlerindeki birçok yenilik; farklı testlerin, farklı ko-kültür modellerinin ve farklı indükleyicilerin kullanılmasına olanak sağlamıştır. Günümüzde birçok doku tipi için optimize edilmiş hücre izolasyon ve kültür modelleri bulunmakla birlikte, aynı süreç paratiroit hücre izolasyonu içinde tamamlanmıştır $(9,12)$. Paratiroit hücreleri için literatürde daha önce bildirilen herhangi bir ko-kültür modeli bulunmamaktadır.

Bu çalışmada izlenen yaklaşım; görece kolay ve nakil sağ kalımının öngörülmesi sürecinin daha az maliyetle belirlenebilmesi için gerçekleştirilmiştir. $\mathrm{Bu}$ amaç doğrultusunda ko-kültür modeli hem ay1rıcı bir bariyer eşliğinde hem de ayırıcı bir bariyer olmadan paratiroit hücreleri ve PKMH için kullanıl- 
mıştır. Ayırıcı bariyer olmadan direkt temas mantığından hareketle, $\mathrm{PKMH}$ hücreleri yabancı paratiroit hücrelerine karşı hem PTH hem de hücre sayısı/ canlılık gibi değişkenler açısından anlamlı bir etki göstermemiştir. Ayırıcı bariyer ile denenen ko-kültür modelinde aynı kültür medyum ortamını paylaşan hücrelerin yine PTH, hücre sayısı/canlılığı gibi parametrelerde anlamlı farklılık oluşturmamıştır. Kontrol grubuna kıyasla iki ko-kültür modelinde de paratiroit hücreleri kültür süresince sayıca azalarak ve PTH salınımı ise artarak devam etmiştir.

Paratiroit hücrelerinin direkt temasla dahi yabancı PKMH'lerinde negatif bir etki oluşturmaması ve aktive edici etki göstermemesi, bu ko-kültür modeli ile nakil öngörüsünü değil fakat olası immünolojik ret yanıtının aksini gösterdiği göz önünde bulundurulmadır. PKMH hücrelerinin farklı aktive edici ajanlarla ko-kültür öncesi hazırlanmamış olması çalışmamanın kısıtlılığı olmasına rağmen temel hedef daha ekonomik bir öngörü belirlenmesidir. İlerleyen çalışmalarda, alıcı-donör kısıtlılıklarının aşılması için daha spesifik ko-kültür modellerinin oluşturulması hedeflenmektedir.

Hakem Değerlendirmesi: Dış bağımsız.

Peer Review: Externally peer-reviewed.

Yazar Katkıları: Çalışma Konsepti/Tasarım-E.Y.; Veri Toplama- S.H.; Veri Analizi/Yorumlama-S.H., B.G.; Yazı Taslağı-S.H., B.G.; İçeriğin Eleştirel İncelemesi-E.Y., B.G.; Son Onay ve Sorumluluk- E.Y., S.H., B.G.; Malzeme ve Teknik Destek-S.H.; Süpervizyon- E.Y.

Author Contributions: Conception/Design of Study- E.Y.; Data Acquisition- S.H.; Data Analysis/ Interpretation- S.H., B.G.; Drafting Manuscript- S.H., B.G.; Critical Revision of Manuscript- E.Y., B.G.; Final Approval and Accountability- E.Y., S.H., B.G.; Technical or Material Support- S.H.; Supervision- E.Y.

Etik Komite Onayı: Bu çalışma için etik komite onayı Yerel Girişimsel Olmayan Etik Kurulu'dan alınmiştır. (No: 71306642-050.01.04)

Ethics Committee Approval: This study was approved by the Local Non-Interventional Ethics Committee. (No: 71306642-050.01.04)
Bilgilendirilmiş Onam: Katılımcılardan bilgilendirilmiş onam alınmıştır.

Informed Consent: Written consent was obtained from the participants.

Çıkar Çatışması: Yazarlar çıkar çatışması beyan etmemişlerdir

Conflict of Interest: Authors declared no conflict of interest.

Finansal Destek: Yazarlar finansal destek beyan etmemişlerdir.

Financial Disclosure: Authors declared no financial support.

\section{KAYNAKLAR}

1. Guibert EE, Petrenko AY, Balaban CL, Somov AY, Rodriguez JV, Fuller BJ. Organ Preservation: Current Concepts and New Strategies for the Next Decade. Transfus Med Hemother. 2011; 38(2):125-42.

2. Chinen J, Buckley RH. Transplantation immunology: solid organ and bone marrow. J Allergy Clin Immunol. 2010;125(2):S324-35.

3. Nawrot I, Woźniewicz B, Tołłoczko T et al. Allotransplantation of cultured parathyroid progenitor cells without immunosuppression: clinical results. Transplantation. 2007 27;83(6):734-40.

4. Ayşan ME, Göncü B, Yücesan E. Paratiroit nakli immünolojisi. Gürol AO, editör. Kök Hücre ve Transplantasyon İmmünolojisi. 1. Bask1. Ankara: Türkiye Klinikleri. 2019;31-8.

5. Pourahmad J, Salimi A. Isolated Human Peripheral Blood Mononuclear Cell (PBMC), a Cost Effective Tool for Predicting Immunosuppressive Effects of Drugs and Xenobiotics. Iran J Pharm Res. 2015;14(4):979.

6. Pekkolay Z, Kılınç F, Soylu $\mathrm{H}$ et al. Alternative treatment of resistant hypoparathyroidism by intermittent infusion of teriparatide using an insulin pump: A case report. Turk J Phys Med Rehabil. 2019;65(2):198-201.

7. Yucesan E, Goncu B, Basoglu Het al. Fresh tissue parathyroid allotransplantation with short-term immunosuppression: 1-year follow-up. Clin Transplant. 2017;31(11):1-4. 
8. Cabane P, Gac P, Amat J et al. Allotransplant of microencapsulated parathyroid tissue in severe postsurgical hypoparathyroidism: a case report. Transplant Proc. 2009;41(9):3879-83.

9. Goncu B, Yucesan E, Ozdemir B, Basoglu H, Kandas NO, Akbas F, Aysan E. A New Transport Solution for Parathyroid Allotransplantation: Effects on Cell Viability and Calcium-Sensing Receptors. Biopreserv Biobank. 2018;16(4):278-84.

10. Alfrey EJ, Perloff LJ, Asplund MW, et al. Normocalcemia thirteen years after successful parathyroid allografting in a recipient of a renal transplant. Surgery. 1992;111(2):234-6.
11. Yucesan E, Goncu B, Ozdemir B, Idiz O, Ersoy YE, Aysan E. Importance of HLA typing, PRA and DSA tests for successful parathyroid allotransplantation. Immunobiology. 2019;224(4):485-9.

12. Bjorklund P, Hellman P. Culture of parathyroid cells. Methods Mol Biol. 2012;806:43-53. 